\title{
Determinants of audit fees: The perception of external auditors
}

\author{
Godfred Matthew Yaw Owusua, Rita Amoah Bekoe ${ }^{b *}$ \\ aDepartment of Accounting, University of Ghana Business School, University of Ghana, gmowusu@gmail.com \\ ${ }^{b}$ Department of Accounting, University of Ghana Business School, University of Ghana, celestialrita@gmail.com \\ ${ }^{*}$ Corresponding author.
}

Received: 25 August 2019, revised: 3 December 2019, accepted: 9 December 2019, published: 14 December 2019.

\begin{abstract}
This paper examines the perception of external auditors on the dominant factors that influence audit fees determination. By means of a survey, the study explored from the perspective of external auditors the level of importance audit firms attach to some identified factors in the determination of audit fees. A self-administered questionnaire was used to gather data from professional auditors working with practicing auditing firms certified and approved by the Institute of Chartered Accountants, Ghana (ICAG). Using a total of 339 valid responses, the study explored the dimensionality of the factors that influence audit fees by employing the Exploratory Factor Analysis (EFA) procedure. Based on the factor structure identified from the EFA, we subsequently evaluated the level of importance auditors perceive these factors to be in the determination of audit fees. The EFA results suggest that audit fees determinants can be grouped into five distinct factors (Audit firm reputation, experience \& expertise; Nature and scope of the audit; Market-wide factor; Client size; Client risk). The factor 'Client risk' was rated to be the most important determinant of audit fees distantly followed by the 'Nature and scope of the audit' factor. The 'Market-wide factor' was rated to be the least important factor in the determination of audit fees. The findings of this study provide some useful insights from the perspective of external auditors on the factors that influence audit fees from a developing country context.
\end{abstract}

Keywords: Audit Fees, External Auditors, Exploratory Factor Analysis, Perception, Developing Countries.

JEL codes: M40, M42

\section{INTRODUCTION}

An auditor's role towards the society is to assure owners and other interested third parties that corporate reports and financial statements provided by management represent a true and fair position of the operations of the company. The independence of the auditor is extremely critical in the performance of this quality assurance role. Recent corporate scandals and the collapse of otherwise vibrant corporations (e.g. Enron and the collapse of Arthur Andersen) have raised concerns and stirred up academic interest in the independence of external auditors and the conduct of quality audits. Key among the issues considered to impair the independence of the auditor is audit fees and the audit firm's economic dependence on a client.

The Handbook (International Auditing, Assurance and Ethics Pronouncements, 2008) of the International Federation of Accountants (IFAC) recognizes that the amount of revenue for the provision of audit and nonaudit services as well as an auditor's economic dependence on a client could pose a threat to the auditor's independence. Beattie, Brandt \& Fearnley (1999) have long established that when a substantial amount of the revenue of an audit firm is received from one client (consistently exceeding 10\%) it could create a potential conflict of interest situation which is likely to impair the independence of the auditor. The Sarbanes Oxley Act (2002) indeed emphasizes that such a threat reduces the quality of an audit. Despite the various laws and regulations promulgated globally to ensure that auditors are seen to be in a position of complete independence, the auditor's professional integrity and the ability to remain independent is still questioned (Dart, 2011).

Empirical studies affirm that the relationship between an audit firm and its client is largely influenced by audit fees (Dart, 2011). This in part explains why in the absence of another meaningful audit-related information, audit fees become an important basis upon which perceptions about audit and related matters are formed by investors 
and other stakeholders (Beck, Fuller, Muriel \& Reid, 2013). Thus, the amount of audit fees charged by audit firms provides a useful basis for assessing not only the perceived independence of the audit firm but also the quality of audit work performed. Due to its importance most especially the perceived link with auditor independence, studies on audit fees have been on the ascendency within the last two decades.

Empirically, extant studies (Dart, 2011; Beck et al, 2013) have found the magnitude of audit fees to be an important predictor of auditor independence and audit quality. In terms of the audit fees and audit quality nexus, several studies (Gupta, Krishnan \& Yu, 2012; Brandon, McMillian \& Stanley, 2012) conclude that low audit fees generally impair the quality of an audit. Hoitash, Markelevich \& Barragato (2007) however, opine that the quality of corporate financial information and the extent of reliance on auditor decision is reduced when audit fees are perceived to be high. Other studies have also employed audit fees as a proxy for determining audit and financial reporting quality (Bentley, Omer \& Sharp, 2011).

The determinants of audit fees have also been a major focus for most academic researchers (AL-Mutairi, Naser \& Al Enazi, 2017; Gonthier-Besacier \& Schatt, 2007; Naser \& Nuseibeh, 2008). The majority of these studies, however, have focused mostly on the association between audit fees and some firm-level characteristics such as company size, profitability, business risk among others (Gonthier-Besacier \& Schatt, 2007; Naser \& Nuseibeh, 2008). While these studies provide some useful insights into the audit fees determinants discourse, the views of the auditors themselves on audit fees determinants have not been the focus of these studies. With the exception of the empirical work of AL-Mutairi, Naser \& Al Enazi (2017) that examined the determinants of audit fees from the perspective of the auditors, most existing studies have relied on secondary data in investigating the factors that affect external audit fees. As pointed out by AL-Mutairi, Naser \& Al Enazi (2017), the determinants of audit fees are contextual and vary from country to country especially from developing an economic perspective.

This study provides some new insight on audit fees' determinants focusing exclusively on the views of external auditors on the dominant factors that influence the amount of audit fees charged by audit firms from a developing country perspective. The evidence we provide in this context is relevant given that most existing studies have focused on the developed world and very few studies on audit fees have considered the views of the auditors. The findings of this study do not only provide some evidence on audit fees' determinants from the Ghanaian setting, but also contribute to the audit fees literature in some important ways. First, this study is among the few existing studies that rely on the views of auditors to examine the factors considered relevant in the determination of audit fees. Prior studies have mostly focused on firm-level factors in examining the predictors of audit fees ignoring the opinions of key actors like the auditors in the audit fees determination discourse. Second, this study unlike the work of AL-Mutairi et al. (2017) uniquely classifies the determinants of audit fees into five distinct groups highlighting the level of importance of each factor in the determination of audit fees from the perspective of auditors.

The remainder of this paper is as follows: the next sections review relevant literature on the determinants of audit fees from a behavioral perspective. The methodology and survey instrument are discussed, followed by the presentation of the results. The final section of this paper draws conclusions on the findings and highlights the key contributions of the study.

\section{LITERATURE REVIEW}

\subsection{The Concept of Audit Fees}

Audit fees generally represents the costs incurred by a business for audit services provided by an auditing firm. The concept of audit fees has been defined by a number of authors in prior literature. Simunic (1980) defines audit fees taking into consideration the number of audit services provided (the amount of work and time) and the unit price. Due to agency costs, businesses usually require an independent third party to verify their financial statements and certify that indeed they are a true reflection of their activities. The remuneration received in the process of such verification is referred to as audit fees (Ahmed \& Abdullah, 2016; Chersan, Robu, Carp \& Mironiuc, 2012; El Gammal, 2012). This definition indicates that businesses incur audit fees to satisfy regulatory requirements and also to show an independent assessment of their activities. El Gammal (2012) further emphasized that the audit fees are usually based on a contractual agreement (an engagement letter) between the auditors and the auditees taking into account time, effort and the number of staff required among others.

Reliability placed on a company's financial information depends largely on the assertions of auditors (audit reports). However, potential investors are usually not privy to the quality of an audit that leads to such assertions except for audit fees that appear on the financial statements. In the absence of such information, audit fees have become a basis upon which potential investors and other stakeholders form perceptions about an audit (Beck et al., 2013). Over the years, studies have used audit fees as a proxy for audit quality and auditor 
independence among others (Bentley et al., 2011; Hoitash et al., 2007). The fees paid to auditors can to some extent affect the quality of the services they provide. On one hand, high fees paid to auditors may get them to put in more effort in the delivery of audit services, thereby increasing the quality of an audit and on the other hand, such high fees may make the auditors economically dependent on a particular client which may also compromise their independence (Hoitash et al, 2007). Thus, audit fees remain an important aspect of audit research. Prior studies have revealed two major reasons for investigating audit fees are to evaluate the competitiveness of the audit market and to also examine the independence of the audit process (Hay \& Knechel, 2006). Al Mutairi et al (2017) also assert that investigating the determinants of audit fees is important since it reflects a company's risk level assumed by an auditor.

\subsection{Determinants of Audit Fees}

\subsubsection{Client Size}

The work of Simunic (1980) indicates that the first point of call in determining how much to charge a client for audit services is the amount of work and the time that the auditor will spend on a client. Impliedly, larger clients will require more time and effort than clients that are considered to be smaller. Consequently, auditors who are engaged by such large companies have to spend more time understanding their complicated internal control systems, designing more audit procedures, conducting more tests of balances as well having client meetings thereby leading to higher audit fees being charged. Such clients usually have high volumes of transactions that may require more time for the auditor to look into. Though a client may have an effective internal control system and hence reducing the audit testing to be done, Stewart \& Munro (2007) suggest that it does not necessarily reduce the effort the auditor puts into the work significantly specialized thereby increasing audit fees. Again, large companies are perceived to have higher agency costs which may result from potential conflict between management and other stakeholders (Inchausti, 1997). In order to reduce agency costs, such large firms tend to disclose more information than smaller ones. In order to give credibility to the information provided, they require the services of external auditors who may have to spend more time to audit such large companies. The most common measure of size in literature has been total assets, number of employees/staff strength as well its turnover.

Extant literature subsequent to the seminal of Simunic (1980) appears to have found the size of an auditee company the most critical explanatory factor on the subject of audit fees (Al-Mutairi et al., 2017; Naser \& Hassan, 2016; Gonthier-Besacier \& Schatt, 2007; Aronmwan \& Okafor, 2015). Findings from these studies suggest that the size of a company has a significant influence on the pricing of audit services. It emerged from these studies that large companies tend to pay higher external audit fees than smaller ones. For instance, Al-Mutairi et al. (2017) found from the perspective of auditors that the size of a client is the most critical element in the determination of audit fees.

\subsubsection{Client complexity}

The complexity of a company has been identified as another critical factor that determines audit fees (Simunic, 1980; Vermeer et al., 2009; Ellis \& Booker, 2011). For companies that are complex and have high volumes of transactions, the auditor will need more time, additional audit procedures and greater expertise in order to carry out such audits. Some studies have also indicated that high growth companies generate a greater degree of complexity, consequently, auditing procedures are usually adjusted significantly to reflect the volumes of transactions undertaken in such companies (Gonthier-Besacier \& Schatt, 2007). These adjustments of audit procedures may sometimes increase the risk of not detecting potential material misstatements in the financial statements. As a result, the auditor is exposed to more professional liability claims (Clatworthy \& Peel, 2006) which may lead to higher audit fees charged by the auditors. A number of proxies have been used as a measure of complexity such as the number of products, business segments, geographic distribution and the proportion of foreign assets. However, the most frequently used measure of complexity in literature has been the number of subsidiaries and/or branches a company has both locally and internationally (Ahmed \& Abdullah, 2016; ElGammal, 2012; Hay, 2013; Audousset-Coulier, 2015).

Empirical literature suggests that there is a significant and positive relationship between the complexity of a company and fees charged for audit services. For instance, Naser \& Nuseibeh (2008) found that external audit fees are significantly related to the complexity of a company. On the other hand, Barakat $\&$ Shaban (2007) suggest that the number of a company's branches is an important determinant of audit fees. 


\subsubsection{Profitability}

The efficient utilization of the resources of a company is expected to result in a higher return on assets. The more income a business generates, the better they are positioned to meet their business expenses and retain some earnings. Thus, profitability is a key measure of management's performance and efficiency in the allocation of resources. In view of this, companies that report higher earnings tend to disclose more information about their performance so as to reduce agency costs and justify their compensation (since their compensation is sometimes based on profits). Such companies are usually a subject of close public scrutiny and auditors will, therefore, perform more testing on revenue recognition and matching expenses to verify such performance figures that may be used to determine compensation. To this end, companies that report higher profits tend to pay high audit fees since the auditor may bill more hours. On the other hand, some studies have also suggested that companies that report lower profit also tend to pay high audit fees. These companies are usually engaged in cost-cutting which may lead to reduced internal control thereby increasing the volume of work to be undertaken by the auditor (Chan et al., 1993).

Empirical studies suggest that audit fees are significantly influenced by the profitability of a company (Joshi and Al-Bastaki, 2000; Ho \& Ng, 1996). Profitability has been measured by the absolute figures of profits or losses, return on assets, return on equity and return on capital employed. These studies have generally reported a significant association between audit fees and corporate profitability.

\subsubsection{Corporate Risk}

Businesses are exposed to various risks and the manner in which management responds to such risks affects both the financial viability of the business and the auditor's approach to auditing it. Some organizations have management control mechanisms to identify, manage, mitigate or control risks. Despite these mechanisms in place, the financial statements may be susceptible to material misstatements arising from identified risks and thus, provide a basis for designing and performing further audit procedures. Consequently, the auditor will analyze the risks associated with the client's business, transactions, and systems which could lead to misstatements in the financial statements, and direct further testing to those risky areas which will attract additional fees (Graham \& Messier Jr, 2006; Wong, 2009). In view of this, some empirical studies suggest that audit fees may be influenced by the perceived risk of audit failure (Chan et al., 1993) i.e. the risk that the auditor expresses an inappropriate opinion when the financial statements are materially misstated.

Empirical evidence on the association between audit fees and corporate risk has been inconsistent. While some studies have found a positive and significant association between the two (Walker \& Casterella, 2000; GonthierBesacier \& Schatt, 2007; Joshi \& Bastaki, 2000; Cameran, 2005), others found the relationship to be insignificant (Naser \& Hassan, 2016; Vermeer et al, 2009). For instance, risk constitutes a significant factor in determining audit fees in France, especially in larger firms where conditions of risk are higher (GonthierBesacier \& Schatt, 2007). Walker \& Casterella (2000) also found that auditors in the US tend to adjust their audit fees to take into account their audit risk arising from the risk assessment of the client. Additionally, the risk is a major factor in determining audit fees in Italy (Cameran, 2005).

\subsubsection{Industry Type}

The extent and nature of audit services provided by auditors will differ across companies in different industries. While some industries are risk-prone and may require more time, effort and specialized audit procedures, others may not require such highly specialized services. Hence companies with high-risk levels are likely to pay more audit fees. For instance, the audit procedure for companies in the banking sector or IT sector may differ considerably from those in the oil and gas industries.

There are several empirical literature that has provided evidence to suggest that audit fees differ across industries. For instance, in France, Gonthier-Besacier \& Schatt (2007) found that companies in the information technology industry paid higher audit fees than companies in other industries. It has also been suggested that manufacturing companies pay more audit fees than companies in other industries (Camfferman \& Cooke, 2002). This is because there is greater public pressure for manufacturing companies to disclose more information (especially about their social and environmental activities) and they tend to have more complex transactions (Tagesson, Blank, Broberg \& Collin, 2009). In order to provide a credible signal about their financial statements and reduce agency costs, such companies usually require high-quality audit which also comes at a higher fee. Also, companies in industries that are highly regulated (e.g. financial institutions) tend to use their financial statements to disclose other information which may require more audit procedures to be designed by the auditor thereby increasing audit fees (Zeghal \& Ahmed, 1990). 


\subsection{Audit firm characteristics}

Empirical studies have indicated that the size of an audit firm has a significant relationship with audit quality and audit fees (Ahmed \& Abdullah, 2016; Choi, Kim, Kim, \& Zang, 2010). The higher the quality of services provided, the higher the price. It has been documented that large audit firms are perceived to provide quality services than smaller ones and that such quality differences are reflected in the prices of audit services. Such large firms are believed to have higher litigation risk exposure and are highly competitive (Al-Harshani, 2008) hence, attracting higher audit fees compared with firms that are perceived to be smaller.

Extant literature suggests that companies that use the services of the 'big four' audit firms or other audit firms affiliated to them tend to have a lower cost of capital (Berry \& Robertson, 2006; Karjalainen, 2011) and also send a signal to stakeholders about management's honesty and integrity.

\section{METHODS}

\subsection{Design, Research Instrument, and Data Collection}

This study adopts the quantitative approach due to the nature of the study objectives. The data for the study was collected by means of a questionnaire which was self-administered to auditors in some selected audit firms in Ghana. To ensure voluntary participation and elicit the honest response, the auditors were assured of the confidentiality of their responses which were to be used for the purposes of the study only. The questionnaire used consisted of two sections. The first section contained information on the key demographic background of the respondents while the second part sought the views of respondents on the factors considered to be relevant in the determination of audit fees. The specific items used in the second part of the questionnaire were adapted from the work of AL-Mutairi et al. (2017) and other previous studies on the determinants of audit fees. Respondents were asked to indicate the level of importance of each of the factors in the determination of audit fees on a seven-point Likert scale, where 1 represents not too important and 7 represents very important.

\section{ANALYSIS AND RESULTS}

\subsection{Respondents}

All auditors working with the 225 accounting firms that have been certified and approved by the Institute of Chartered Accountants, Ghana (ICAG) as of December 2015 constituted the population for this study. ICAG classifies practicing firms in good standing into five broad divisions based on their revenue and size like A1, A, B1, B, C, and D. The Big Four auditing firms (PWC, KPMG, Deloitte and Ernst \& Young) constitute the A1 category based on size and revenue generation capacity whilst all local auditing firms are grouped into the remaining four in descending order. A total of 650 questionnaires were distributed to the respondents across the five divisions. 400 of the questionnaires were duly returned but 339 valid responses were included in the final analysis.

As shown in Table 1 the sample was dominated by the males accounting for $67 \%$ of the total responses. The majority of the respondents (approximately $84 \%$ ) belong to the youthful year group between the ages of 20 and 40 years. With regards to the academic qualifications, about half of the respondents have had their first degree $(49.9 \%)$ with a membership certificate with a recognized professional accountancy body: that is either with the Instituted of Chartered Accountants, Ghana or Association of Certified Chartered Accountants. The majority of the respondents have also acquired 3 to 7 years of work experience while a fairly significant number of the respondents were from local audit firms that are affiliated to international audit firms.

\subsection{Data analysis procedures}

A major goal of the current study was to ascertain the level of importance auditors perceive the identified factors to be in influencing auditing fees. However, before proceeding with this analysis, an exploratory factor analysis was conducted on the factors in order to identify the factor structure that determines audit fees. This approach was necessary to properly structure and summarize the responses on the relevance of these factors in determining auditing fees. An analysis of the respondents' view on the factors that influence audit fees determination in Ghana is subsequently provided based on the factor structure that emerged from the exploratory factor analysis. 
Table 1. Descriptive summary of demographics

\begin{tabular}{lrr}
\hline \multicolumn{1}{c}{ Variables } & Frequency & Percent \\
\hline Gender & & \\
Male & 227 & 67 \\
Female & 112 & 33 \\
Age & & \\
Less than 30 & 136 & 40.1 \\
30-40 & 147 & 43.4 \\
41-50 & 34 & 10.0 \\
51 \& above & 22 & 6.5 \\
Level & & \\
Bachelor & 169 & 49.9 \\
Masters & 110 & 32.4 \\
Ph.D & 8 & 2.4 \\
Others & 52 & 15.3 \\
Professional & & \\
Yes & 94 & 27.7 \\
No & 245 & 72.3 \\
Work Experience & & \\
Less than 30 & 79 & 23.3 \\
3-7 & 148 & 43.7 \\
8-10 & 43 & 12.7 \\
11 \& above & 69 & 20.4 \\
Firm Status & & \\
Local & & \\
Affiliated to international & 155 & 45.7 \\
ICAG Classification & 184 & 54.3 \\
A1 & & \\
A & 147 & 43.4 \\
B1 & 57 & 16.8 \\
B & 48 & 14.2 \\
C & 46 & 13.6 \\
D Big Four Audit Firms & 21 & 6.2 \\
Yes & 20 & 5.9 \\
No & 145 & 42.8 \\
\hline & 194 & 57.2 \\
\hline
\end{tabular}

\subsection{Exploratory Factor Analysis (EFA)}

The principal component extraction criterion using the varimax rotation method was employed in conducting the EFA. Tests for model sampling adequacy yielded satisfactory results, as the values of the Kaiser-Meyer-Olkin measure of sampling adequacy of 0.87 was above the recommended threshold of 0.7 (Kaiser 1970; Kaiser and Rice 1974). Bartlett's test of sphericity also confirms the presence of correlations between the indicators of each construct, and this test yielded statistically significant results, an indication of the appropriateness of the data set for EFA. The results of the factor analysis and the factor loading of each item are presented in Table 2. The Oblimin rotation yielded five factors explaining a total variance of $63.15 \%$ with the Eigenvalue of each factor greater than one.

Factor one which explains the highest amount of variation (14.94\%) consisted of indicators such as the reputation of the audit firm, experience, expertise and caliber of audit staff working in the audit firm. This factor was labeled as "Audit firm Reputation, Experience \& Expertise" as they generally describe the factors that bother on the image and technical competencies of the audit firm. Factor two was made up of five items that describe, generally, the scope and nature of the audit and accounted for $14.13 \%$ of the variation. This factor was labeled as "nature and scope of the audit". Factor three consisted of six items ranging from proximity to the client firm to the extent of the client's use of ICT. Taken together, this factor was labeled as "market-wide factors". The fourth factor referred to as "Client Size" consisted of items that described the stature of the client business in terms of size and included items such items as the level of profitability, the asset base of the client firm and revenue generation capacity. The last factor contained two indicators: the effectiveness of the internal control system of the client and the risk faced by the audit firm. We labeled this factor as "Client Risk" as they largely describe the risks that may be associated with the audit work. Thus, the EFA results demonstrate that the factors 
that influence audit fees could be grouped into five mutually exclusive categories whose components correlate loosely with each other.

Table 2. Results of EFA, Rotated Component Matrix

\begin{tabular}{|c|c|c|c|c|c|}
\hline & $\begin{array}{c}\text { Factor } \\
1\end{array}$ & $\begin{array}{c}\text { Factor } \\
2\end{array}$ & $\begin{array}{c}\text { Factor } \\
3\end{array}$ & $\begin{array}{c}\text { Factor } \\
4\end{array}$ & $\begin{array}{c}\text { Factor } \\
5\end{array}$ \\
\hline Reputation of the audit firm & .765 & & & & \\
\hline Industry expertise & .743 & & & & \\
\hline Experience in auditing similar firms & .743 & & & & \\
\hline Academic qualifications of the audit firm's staff & .741 & & & & \\
\hline Scope of operations & & .739 & & & \\
\hline Complexity of the audit process & & .717 & & & \\
\hline Number of subsidiaries and branches of the client firm & & .713 & & & \\
\hline Activities of the client's firm & & .590 & & & \\
\hline Short audit report time lag & & .551 & & & \\
\hline Proximity to the client firm & & & .717 & & \\
\hline Strict local regulations & & & .617 & & \\
\hline Financial and economic instability & & & .614 & & \\
\hline Cumulative knowledge of the client business & & & .562 & & \\
\hline Financial leverage of the client firm & & & .534 & & \\
\hline The extent of the client's use of information technology & & & .517 & & \\
\hline Level of profitability of client firm & & & & .796 & \\
\hline Total assets of the client & & & & .753 & \\
\hline Total sales and revenue of the client & & & & .742 & \\
\hline The effectiveness of the client's internal control system & & & & & .768 \\
\hline Risk faced by the audit firm & & & & & .563 \\
\hline Eigenvalues & 2.988 & 2.827 & 2.749 & 2.529 & 1.537 \\
\hline Percentage of variance explained & 14.938 & 14.134 & 13.743 & 12.643 & 7.687 \\
\hline
\end{tabular}

\section{Analysis of respondents' views on the factors that influence audit fees in Ghana}

Having explored the dimensions of the factors that influence audit fees, we subsequently evaluated the level of importance respondents perceive these factors to be in influencing audit fees based on the groupings. Table 3 presents the mean scores and standard deviations of the respondents' views on the importance of factors that affect audit fees for each group and the individual factors that make up the group

The "Audit firm Reputation, Experience \& Expertise" factor had an overall mean of 5.41 which suggests that the respondents were in a strong agreement in terms of the importance of this factor in the determination of audit fees. Among the four indicators that describe this factor, the indicator "reputation of the audit firm" recorded the highest mean of 5.54 with academic qualification of audit firm staff being the least ranked item in terms of importance (mean= 5.28). Instructively, all the four indicators had mean scores above 5.0 which indicates that all the items were highly ranked by the respondents to be very important in determining audit fees. Thus, apart from the reputation of the audit firm, the experience and expertise of auditors within the firm are also important determinants of the amount of audit fees charged by the firm. The argument supporting the reputation of the audit firm being ranked as the most important factor is that audit firms with long-standing practicing experience are usually known in the market place and are perceived to offer quality services than other audit firms. They are regarded as having an enormous amount of experience and have the ability to draw on other network of partner firms to deal with issues. Most entities value having access to practicing firms that are able to provide local solutions in a global environment and are therefore willing to pay some premium for such services. This, inevitably, influences the fees charged by such firms.

Moreover, such firms usually have very qualified and experienced audit staff with the capacity to undertake complex and highly complicated audit work. These important qualities require significant financial investments and directly affect the price build-up (often determined as a rate per hour) of such firms making very reputable firms relatively expensive than their compatriots. Empirically, existing studies (Vermeer et al. 2009: Choi et al. 2010; Verbruggen et al. 2011; Wang et al. 2009; El-Gammal 2012) have shown that the reputation of an audit firm characterized by international visibility, the presence of highly qualified and experienced staff has important implications on audit fees. Again, reputable audit firms with the requisite skill sets and expertise usually have a high demand for their services which directly affect their service charge (Palmrose, 1986). 
The "nature and scope of the audit" factor had an overall mean of 5.71 which suggests that the respondents were in a strong agreement in terms of the importance of this factor in the determination of audit fees. Among the five indicators that describe this factor, the indicator "complexity of the audit process" recorded the highest mean score of 6.07 with "short audit report time lag" being the least ranked item in terms of importance (mean=4.96). Taken together, four out of the five indicators under this construct had mean scores above 5.0 which is an indication that most of the items under this construct were highly ranked by the respondents to be very important in determining audit fees.

A complex audit is often one that requires a significant investment of time in order to deal with all the tasks associated with the audit. For instance, the audit of an entity with subsidiaries all over the world will require a lot of time in visiting locations where there are material holdings of items such as inventory and property, plant and equipment. The auditing standards, International Standards on Auditing (ISAs) make it mandatory for the auditor to visit such locations such to obtain audit evidence about the existence and condition of these items. These procedures involve cost (in terms of travel time and cost, and the actual time incurred in executing the procedures) that would be borne by the audit firm and eventually passed on as fees to the client. Consolidating accounts of such clients can be equally complex. Such clients may have various levels of sub-consolidation and eventual top-level consolidation in order to prepare a consolidated financial statement. All these would have to be reviewed by the auditor and thus, affects the fees that are charged. As argued by Blankley, Hurtt, \& Macgregor (2015), complex tasks lead to longer audit engagement requiring more resources in terms of time and personnel to carry out the audit task which affects the fees that are charged.

Table 3. Descriptive statistics on audit fees determinants

\begin{tabular}{|c|c|c|}
\hline Descriptive Statistics & Mean & $\begin{array}{l}\text { Standard } \\
\text { Deviation }\end{array}$ \\
\hline \multicolumn{3}{|l|}{ Auditor Expertise and Experience } \\
\hline Reputation of the audit firm & 5.54 & 1.43 \\
\hline Industry expertise & 5.49 & 1.36 \\
\hline Experience in auditing similar firms & 5.28 & 1.44 \\
\hline Academic qualifications of the audit firm's staff & 5.35 & 1.65 \\
\hline Overall Mean & 5.41 & \\
\hline \multicolumn{3}{|l|}{ Nature and scope of the audit } \\
\hline Scope of operations & 5.96 & 1.26 \\
\hline Complexity of the audit process & 6.07 & 1.17 \\
\hline Number of subsidiaries and branches of the client firm & 6.04 & 1.27 \\
\hline Activities of the client's firm & 5.51 & 1.45 \\
\hline Short audit report time lag & 4.96 & 1.51 \\
\hline Overall Mean & 5.71 & \\
\hline \multicolumn{3}{|l|}{ Market-wide Characteristics } \\
\hline Proximity to the client firm & 3.96 & 1.79 \\
\hline Strict local regulations & 4.94 & 1.55 \\
\hline Financial and economic instability & 4.78 & 1.50 \\
\hline Cumulative knowledge of the client business & 5.11 & 1.39 \\
\hline Financial leverage of the client firm & 4.80 & 1.47 \\
\hline \multirow{2}{*}{$\begin{array}{l}\text { The extent of the client's use of information technology } \\
\text { Overall Mean }\end{array}$} & 5.33 & 1.32 \\
\hline & 4.82 & \\
\hline \multicolumn{3}{|l|}{ Size } \\
\hline Level of profitability of client & 4.88 & 1.57 \\
\hline Total assets of the client & 4.89 & 1.61 \\
\hline Total sales and revenue of the client & 5.47 & 1.49 \\
\hline Overall Mean & 5.08 & \\
\hline \multicolumn{3}{|l|}{ Client Risk } \\
\hline The effectiveness of the client's internal control system & 5.71 & 1.36 \\
\hline Risk faced by the audit firm & 6.14 & 1.33 \\
\hline Overall Mean & 5.93 & \\
\hline
\end{tabular}


The "market-wide characteristics" construct had a mean score of 4.82, suggesting that the respondents agreed that the indicators under this construct are important in determining audit fees. The "extent of the client's use of information technology" indicator under this factor recorded the highest mean score of 5.33 while "proximity to the client" recorded the least mean score of 3.96. A strong information technology (IT) environment goes a long way in reducing risks associated with the audit. Once there is extensive use of IT, the auditor is able to assess and rely on information generated from the client's systems. This reduces the level of effort required in verifying reports as well as documents generated from the system and reduces the cost of the audit and the associated audit fees. Conversely, a weak environment in terms of the use of IT increases the risk associated with the audit. The auditor would have to spend more effort on verifying information provided by the client.

The extra effort in performing these verification procedures results in additional cost which is passed on as fees to the client. Another factor that scored high (5.11) based on the responses of respondents is the cumulative knowledge of the client's business. As the auditor gets to understand the nature of the client's business model, operations, people and systems, the audit becomes more efficient and the efficiency gains reduce the cost of the audit. Clients are therefore able to leverage on that during negotiation of audit fees in order to get a reduction in the audit fees. On the contrary, the lack of knowledge by the auditor of the client's business model, operations, people and systems tends to increase the cost of the audit and the fees associated with the audit. First-year audits, for example, tend to be more expensive than continuing audits as there is always a learning curve the auditor goes through in first-year audits. This invariably affects the cost of the audit and the fees charged by practicing firms.

The "Size of Client Firm" factor had an overall mean of 5.08 which suggests that respondents were in strong agreement that the size of the organization is an important factor in the determination of audit fees. Amongst the three indicators that describe the size of a firm as a determinant of audit fees, the indicator "Total sales and revenue of the client" recorded the highest mean score of 5.47 with the least ranked being "Level of profitability of client firm" with a mean score of 4.88. This demonstrates that the size of a firm measured in terms of its profitability, revenue streams, and its assets base is relevant in determining the amount of audit fees to be charged by the audit firm. Total sales and revenue of the client gives an indication of the audit effort required to complete the audit. The more significant the numbers in the financial statements such as revenue, the more time required to audit those numbers. On the other hand, the less significant the numbers in the financial statements, the less the audit effort required. A case in point is the obvious disparity in fees one would find when a comparison is made between the fee charged by an audit firm for a start-up company that has only stated capital and cash as the items in its financial statements and a company that is fully operational.

The "Client Risk" factor had an overall mean of 5.93 which suggests that respondents were in firm agreement that this is a significant factor in determining audit fees. Between the two indicators that describe the risk involved in the audit process as a determinant of audit fees, the indicator "risk faced by the audit firm" recorded the higher mean score of 6.14 . Although this means that respondents consider 'risk faced by the audit firm' as more important than 'the effectiveness of the client's internal control system' in determining audit fees, the two indicators with mean scores above 5.0 were considered very important in coming up with audit fees. In other words, the effectiveness of the client's internal control system and the risk faced by the audit firm in conducting the audit matters substantially in charging audit fees.

For example, companies that are significant subsidiaries of the United States of America Public Company Accounting Oversight Board (PCAOB) are likely to pay more audit fees than stand-alone entities that operate only in Ghana. This is because the risk associated with performing a PCAOB engagement is higher than that associated with a non-PCAOB engagement. Under PCAOB requirements, an auditor is expected to issue two sets of opinions. One of them on the internal controls over financial reporting and the other opinion on the financial statements. The issuance of the two opinions means the auditor assumes additional risk as compared to an engagement that is not-PCAOB where the auditor issues only one opinion on the financial statements

\section{CONCLUSIONS}

The overall purpose of this study was to investigate, from the perspective of external auditors, the factors they consider relevant in the determination of audit fees in Ghana. While studies on audit fees and its determinants have been conducted in the past, the current study contributes to the few existing studies that examine the phenomenon by relying on the opinions of the auditors on the relevance of some identified factors in the determination of audit fees. In particular, the paper explored the dimensionality of the factors that influence audit fees and also ascertained the degree of importance auditors perceive these factors to be in determining audit fees. A total of 339 valid responses from professional auditors working with practicing auditing firms certified and approved by the Institute of Chartered Accountants, Ghana (ICAG) were used in our empirical analysis. 
Results of the Exploratory Factor Analysis using the Principal component analysis criterion revealed the presence of five factors explaining a total of $63.7 \%$ of the variance. Thus, this study classified the factors that influence audit fees into five distinct groups labeled as Audit firm Reputation, Experience \& Expertise, Risk, nature, and scope of the audit, market-wide factors, and Size of Client Firm. An assessment of the level of importance auditors perceive these factors to be in influencing auditing fees also demonstrates that all the factors are considered to be important determinants of audit fees but in varying degrees. While the respective mean scores for the five factors exceeded the mid-point value of 3.5, the factor "Client Risk" was rated the most important factor among all the factors with an overall mean of 5.93. The "market-wide factors" on the other hand was rated by the auditors to be the least important factor as it recorded the lowest mean score (4.82). Among all the indicators, the indicator "risk faced by the audit firm" was rated the most important determinant of audit fees (mean=6.14) by the auditors while the indicator "proximity to the client firm" was adjudged the least important factor in determining audit fees.

The findings of this study do not only highlight the factor structure of the audit fees' determinants but also emphasize the level of importance auditors perceive these factors to be in the determination of audit fees. While the present study shed some light on the views of professional accountants on audit fees determinants, the evidence we provide is based on the views of a few professional accountants in Ghana. This to a large extent may affect the extent of generalization of the study findings but provides an important avenue for further research in the area.

\section{REFERENCES}

Ahmed, R. A. \& Abdullah, H. A. (2016). A proposed framework of audit fees determinants in the Kurdistan region. European Journal of Business and Management, 8(12).

Al-Harshani, M. O. (2008). The pricing of audit services: evidence from Kuwait. Managerial Auditing Journal, 23(7), 685696. https://doi.org/10.1108/02686900810890643

Al Mutairi, A., Naser, K. \& Al Enazi, N. (2017). An empirical investigation of factors affecting audit fees: evidence from Kuwait. International Advances in Economic Research, 23, 333-347. https://doi.org/10.1007/s11294-017-9649-5

Aronmwan, EJ, \& Okafor, CA (2015). Auditee characteristics and audit fees: An analysis of Nigerian quoted companies. Journal of Social and Management Sciences, 10(2), 68-79.

Audousset-Coulier, S. (2015). Audit fees in a joint audit setting. European Accounting Review, 24(2), 347-377. https://doi.org/10.1080/09638180.2014.892787

Beattie, V., Brandt, R. \& Fearnley, S. (1999). Perceptions of auditor independence: U.K. evidence. Journal of International Accounting, Auditing, and Taxation, 8(1), 67-107. https://doi.org/10.1016/S1061-9518 (99)00005-1

Beck, A. K., Fuller, R. M., Muriel, L. \& Reid, C. D. (2013). Audit fees and investor perceptions of audit characteristics. Behavioral Research in Accounting, 25(2), 71-95. https://doi.org/10.2308/bria-50403

Bently, K. A., Omer, T. C. \& Sharp, N. Y. (2011). A business strategy, audit effort, and financial reporting irregularities. Working Paper, Texas A \& M University.

Berry, A. and Robertson, J., 2006. Overseas bankers in the UK and their use of information for making lending decisions: changes from 1985. British Accounting Review, 38 (2), 175-191. https://doi.org/10.1016/j.bar.2005.10.004

Brandon, D. M., McMillan, J. J. \& Stanley, J. D. (2012). Does lowballing impair audit quality? Evidence from client accruals surrounding analyst forecasts. Paper presented at the AAA Midyear Auditing Section Conference, Savannah, GA, January https://doi.org/10.1016/j.jaccpubpol.2015.05.007

Cameran, M. (2005). Audit fees and the large auditor premium in the Italian market. International Journal of Auditing, 9(2), 129-146. https://doi.org/10.1111/j.1099-1123.2005.00205.x

Camfferman, K., \& Cooke, T. E. (2002). An analysis of disclosure in the annual reports of UK and Dutch companies. Journal of International Accounting Research, 1(1), 3-30. https://doi.org/10.2308/jiar.2002.1.1.3

Clatworthy, M. A., \& Peel, M. J. (2007). The effect of corporate status on external audit fees: evidence from the UK. Journal of Business Finance \& Accounting, 34(1-2), 169-201. https://doi.org/10.1111/j.1468-5957.2006.00658.x

Chan, P., Ezzamel, M., \& Gwilliam, D. (1993). Determinants of audit fees for quoted UK companies. Journal of Business Finance \& Accounting, 20(6), 765-786. https://doi.org/10.1111/j.1468-5957.1993.tb00292.x

Chersan, I. C., Robu, I. B., Carp, M. \& Mironiuc, M. (2012). A circular casualty analysis on the determinants of audit fees within the NYSE - Quoted companies. Communications of the IBIMA, 1. https://doi.org/10.5171/2012.896676

Choi, J. H., Kim, C., Kim, J. B., \& Zang, Y. (2010). Audit office size, audit quality, and audit pricing. Auditing: A Journal of Practice \& Theory, 29(1), 73-97. https://doi.org/10.2308/aud.2010.29.1.73

Clatworthy, M. A. \& Peel, M. J. (2006). The effect of corporate status on external audit fees: evidence from the UK. Journal of Business Finance and Accounting, 1(2), 169-201. https://doi.org/10.1111/j.1468-5957.2006.00658.x

Dart, E. (2011). UK investors' perceptions of auditor independence. The British Accounting Review, 43, $173-185$. https://doi.org/10.1016/j.bar.2011.06.003 
El Gammal, W. (2012). Determinants of audit fees: Evidence from Lebanon. International Business Research, 5(11), 136145. http://hdl.handle.net/20.500.11889/4280

Ellis, Y. \& Booker, Q. L. (2011). Audit fee determinants in the non-profit sector: A study of community action agencies. Faculty Publications, Columbia State University. https://csuepress.columbusstate.edu/bibliography_faculty/88

Gonthier-Besacier, N., \& Schatt, A. (2007). Determinants of audit fees for French quoted firms. Managerial Auditing Journal, 22(2), 139-160. https://doi.org/10.1108/02686900710718654

Gupta, P. P., Krishnan, G. \& Yu, W. (2012). Do auditors allow earnings management when audit fees are low? Working Paper, Lehigh University, and Singapore.http://dx.doi.org/10.2139/ssrn.1836829

Hay, D. (2013). Further evidence from meta-analysis of audit fee research. International Journal of Auditing, 17, $162-176$. https://doi.org/10.1111/j.1099-1123.2012.00462.x

Hay, D. C. \& Knechel, W. R. (2006). Audit fees: A meta-analysis of the effect of supply and demand attributes. Contemporary Accounting Research, 23(1), 141-191. https://doi.org/10.1506/4XR4-KT5V-E8CN-91GX

Ho, S. W., \& Ng, P. P. (1996). The determinants of audit fees in Hong Kong: an empirical study. Asian Review of Accounting, 4(2), 32-50. https://doi.org/10.1108/eb060673

Hoitash, R., Markelevich, A. \& Barragato, C. A. (2007). Auditor fees and audit quality. Managerial Auditing Journal, 22(8), 761-786. https://doi.org/10.1108/02686900710819634

Inchausti, B. G. (1997). The influence of company characteristics and accounting regulation on information disclosed by Spanish firms. European Accounting Review, 6(1), 45-68.https://doi.org/10.1080/096381897336863

Joshi, P. L. \& Al-Bastaki, H. (2000). Determinants of audit fees: Evidence from the companies listed in Bahrain. International Journal of Auditing, 4, 129-138.https://doi.org/10.1111/1099-1123.00308

Karjalainen, J., (2011). Audit quality and cost of debt capital for private firms: evidence from Finland. International Journal of Auditing, 15 (1), 88-108. https://doi.org/10.1111/j.1099-1123.2010.00424.x

Naser, K. \& Nuseibeh, R. (2008). Determinants of audit fees: Empirical evidence from an emerging economy. International Journal of Commerce and Management, 17(3), 239-254. http://hdl.handle.net/20.500.11889/4280

Naser, K., \& Hassan, Y. M. (2016). Factors influencing external audit fees of companies listed on Dubai Financial Market. International Journal of Islamic and Middle Eastern Finance and Management, 9(3), $346-363$. https://doi.org/10.1108/IMEFM-01-2015-0007

Palmrose, Z. V. (1986). Audit fees and auditor size: Further evidence. Journal of Accounting Research, 24(1), 97-110. https://www.jstor.org/stable/2490806

Simunic, D. A. (1980). The pricing of audit services: Theory and evidence. Journal of Accounting Research, 18(1), 161-190. DOI: 10.2307/2490397 https://www.jstor.org/stable/2490397

Stewart, J. \& Munro, L. (2007). The impact of audit committee existence and audit committee meeting frequency on the external audit: Perceptions of Australian auditors. International Journal of Auditing, 11, 51-69. https://doi.org/10.1111/j.1099-1123.2007.00356.x

Tagesson, T., Blank, V., Broberg, P., \& Collin, S. O. (2009). What explains the extent and content of social and environmental disclosures on corporate websites: a study of social and environmental reporting in Swedish listed corporations. Corporate Social Responsibility and Environmental Management, 16(6), 352-364. https://doi.org/10.1002/csr.194

Verbruggen, S., Christiaens, J., Reheul, A. M., \& Van Caneghem, T. (2011). Audit pricing in a reformed non-profit market. HUB Research Papers.

Vermeer, T. E., Raghunandan, K. \& Forgione, D. A. (2009). Audit fees at US non-profit organizations. Auditing: A Journal of Practice and Theory, 28(2), 289-303. https://doi.org/10.2308/aud.2009.28.2.289

Walker, P. L., \& Casterella, J. R. (2000). The role of auditee profitability in pricing new audit engagements. Auditing: $A$ Journal of Practice \& Theory, 19(1), 157-167. https://doi.org/10.2308/aud.2000.19.1.157

Wang, K., Sewon, O., \& Iqbal, Z. (2009). Audit pricing and auditor industry specialization in an emerging market: Evidence from China. Journal of International Accounting, Auditing, and Taxation, 18(1), 60-72. https://doi.org/10.1016/j.intaccaudtax.2008.12.006

Wong, S. (2009). Audit pricing in Australia in the 2000s. International Review of Business Research Papers, 5(3), 82-89. 